\title{
DE FACTO MUNICIPAL CORPORATIONS UNDER UNCONSTITUTIONAL STATUTES
}

\author{
CHARLES W. TOOKE
}

The doctrine of de facto municipal corporations ${ }^{2}$ is one peculiar to American law, developed by our courts from the English doctrine of de facto officers to meet the complex situations arising from time to time due to the constantly shifting bases of our municipal organization. Briefly stated, the doctrine is that where there is authority in law for a municipal corporation, the organization of the people of a given territory as such a corporation under color of delegated authority, followed by an user in good faith of the governmental powers incidental thereto, will be recognized by the law as a municipal corporation de facto, wherever through the failure to comply with the constitutional or statutory requirements the corporation cannot be said to exist de jure.

The resulting incidents of such a status are that the organization itself and those dealing with it as a corporation cannot attack its existence, that its acts are as valid as those of a de jure corporation, and that the legality of its existence cannot be inquired into collaterally, but may be challenged only by the state itself in quo warranto proceedings. When the question of the corporate entity of any municipality is raised, therefore, except by the state itself, the inquiry must first be directed to determine whether the law and the facts are sufficient to establish its de facto status. The facts as to the attempt to organize and as to user of the franchises in good faith are usually easily determined. No especial difficulty, moreover, can arise where the corporation has organized itself under authority of a valid statute and has failed to acquire a de jure status through non-compliance with some of the conditions prescribed as precedent thereto, but a more serious question often must be faced where the statute itself under which the corporation purports to organize is later declared to be unconstitutional. MTay such a statute be regarded as giving the color of authority required by the de facto doctrine? MIay it in itself constitute a creative legislative power sufficient to give corporate vitality to the organization that lays claims to a legal personality? This question is one that has given great difficulty to our courts and has led to two well defined schools of thought. While but a subordinate phase

1 The term municipal corporations in this article is used generically and includes all local corporate governmental agencies. 
of the de facto doctrine, its consideration is essential to any clear understanding of the conflicting opinions of our courts.

The question of the existence of de facto offices or of de facto municipal corporations has never arisen in England. With the exception of those corporations which came into existence as by common law, the creative source lay either in the legislation of Parliament or the prerogative of the crown. ${ }^{2}$ The mass of franchises which in the early days were denominated firma burgi, being grants from the king, were considered as quasi-contractual and required the consent of the grantee, a requirement that continued applicable to all incorporations by the crown. ${ }^{3}$ The creation of municipal corporations by Parliament, however, never required the assent of the incorporators, being founded on the supreme legislative power asserted by that body. ${ }^{4}$ By the Act of $1835^{5}$ practically all the existing municipal corporations were placed under parliamentary control, and since that dato no new corporation has been erected by the crown. ${ }^{\circ}$ From the supremacy of Parliament it follows that any office it creates cannot be called in question by the courts; however its creation may violate the established constitutional principles, the courts must recognize it and give it support. Even prior to the full development of the modern doctrine of parliamentary supremacy, the court had held that the right of any corporation to exercise its franchises could be tested only by quo warranto brought by the attorney-general. In Rex $v$. Stacey "Mansfield and Buller arbitrarily fixed the time within which the king himself could bring quo warranto to six years, and stated that without question in many cases the time should be further limited. ${ }^{\mathrm{a}}$

Upon the organization of the American states under the tripartite theory of the written constitution, all the residuary powers of government formerly comprehended in the prerogative of the crown, if not reserved to the people, became vested in the legislative branch. ${ }^{9}$ Hence, under our system no municipal corporation can exist except as created directly or indirectly by the legislative power. All powers of local self-government are predicated upon the legislative fiat of the state. Even the unique municipal corporation known as the New England town

2 Incorporation by prescription was of course recognized.

3 Wilcock, Municipal Corporations (1827) 30.

4 Ibid. 25.

5 See preamble, (1882) $45 \& 46$ Vict. c. 50.

6 (1835) $5 \& 6 \mathrm{Wm}$. IV, c. 76.

i T. R. 1 (1785).

${ }^{8}$ Since the Municipal Corporations Act of 1832, obviously no municipal corporation other than de jure can exist, and the act itself expressly limits the time within which the regularity of the election of an officer can bo tested to twelve months.

${ }^{\prime} 1$ Cooley, Constitutional Limitations (8th ed. 1927) 175. 
has uniformly been held to have derived its powers by virtue of the colonial charter or by grant of the colonial legislature, and to have been without any inherent power of local self-government. ${ }^{10}$ This legislative power may be exercised by the sovereign through the state constitution, either by express creation of local governmental agencies, ${ }^{11}$ by the indirect recognition of their existence, or by direct validation of irregular organizations purporting to act as municipal corporations. ${ }^{22}$ Usually, however, it has been delegated to the state legislature, but with the recent adoption of constitutional home rule it has in many states been largely committed to the electors of the municipal territory, to be exercised through the complicated machinery of the popular initiative and referendum.

Subsequent to the organization of the state governments, and down to the middle of the nineteenth century, the state legislatures were unrestricted in the exercise of their power to create municipal corporations. This was the era of special charters for cities and villages and any failure to follow the method of incorporation designated by the legislature, as well as the lack of any power attempted to be exercised by a municipal corporation, was easily remedied by a validating statute. During this period, in many instances the courts applied the doctrine of legislative recognition by acquiescence or by acts subsequent to incorporation to cure the defective organization, ${ }^{13}$ a doctrine which in these later days has given rise to the principle of estoppel of the state to question the validity of incorporation.

With the adoption of the constitutional amendments limiting the power of the legislature to incorporate or amend charters except by general act, beginning with Ohio and Indiana in 1851, and rapidly followed by other states, ${ }^{12}$ questions soon were raised in the several states as to the validity of statutes classifying municipal corporations by population or otherwise, by which method the legislature sought to meet the diverse needs of cities and villages without overstepping the constitutional inhibitions. As a general rule reasonable classifications, usually based upon

10 Webster v. Harwinton, 32 Conn, 131 (1864); Newport v. Horton, 22 R. I. 196 (1900); Commonwealth v. Roxbury, 75 Mass. 451 (1857), note by the reporter, Horace Gray, Jr., at 503.

11 The City of Denver, for example, is created by the Constitution of Colorado.

12 City of Guthrie v. Territory, 1 Okla. 188, 31 Pac. 190 (1892).

13 Bow v. Allenstown, 34 N. H. 351 (1857); Commissioners of Bath v. Boyd, 23 N. C. 194 (1840). See, also, State v. Leatherman, 38 Arl. 81 (1881); Comanche County v. Lewis, 133 U. S. 198, 10 Sup. Ct. 286 (1890).

14 Iowa, 1857; Kansas, 1859; Nevada, 1864; Nebraska, 1867; Arliansas, 1868; Illinois, Virginia, Tennessee, 1870; West Virginia, 1872; Pennsylvania and Texas, 1873; New Jersey and Missouri, 1875; California and Louisiana, 1879. 
population, were upheld, but frequently the temptation to enac: special legislation led to the passing of statutes plainly repugnant to the constitutional limitations. In Ohio, for example, the legislature with the occasional approval of the courts practically ignored the restrictive provisions of the constitution upon the creation of municipalities and the amendment of their charters, until in 1902 the supreme court in State v. Jones ${ }^{16}$ and State v. Beacon, ${ }^{16}$ overruling its previous decisions, held that the existing classification of cities for purposes of legislation was inhibited by the constitution. Under the statutes as they operated at this time, each of the eleven principal cities fell into a separate class. So serious was the effect of the decision in the second case affecting the continuity of the government of Cleveland that the execution of the judgment of ouster was suspended by the court for three months to enable the legislature and the city of Cleveland to conform to the requirements of the decision. In State v. Beacom, as in numerous other cases, the court was directly driven to one of two alternatives as to the erstwhile status of the city and the validity of the official acts pending its operation under unconstitutional statutes,-either to hold the state estopped to contest the validity of the statutes in question because of its long acquiescence, or to hold that the city had been acting as a de facto corporation, whose acts were not subject to collateral attack and whose status could only be challenged at the instance of the state itself. This latter alternative was adopted, the court finding itself justified by the principle established in State $v$. Gardner, eight years previously. ${ }^{17}$

The inclusion of restrictive limitations upon the creation of municipal corporations in the state constitutions, the multiplication of quasi-municipal agencies, the adoption of home-rule amendments with uncertain provisions governing their exercise by the local electorate, have all within more recent years given rise to innumerable attacks upon the validity of municipal organizations. ${ }^{18}$ Despite the efforts in many instances to forestall the issue by general validating acts, either constitutional or legislative, ${ }^{19}$ the great burden of working out the resulting problems was thrown upon the courts. Their reception and assimilation of new political theories to existing legal precedents constitute a notable contribution to constructive legislation. To

1566 Ohio St. 453,64 N. E. 424 (1902).

1666 Ohio St. 491,64 N. E. 427 (1902).

1754 Ohio St. 24, 42 N. E. 999 (1896).

18 The number of cases in which this issue is involved may bo botter appreciated when we recall that every annexation of territory is in effect pro tanto a new incorporation.

18 As examples of general validating acts, see Wis. Laws 1883, c. 54; Laws 1897, c. 5; Minn. Laws 1897, c. 3; Ark. Acts 190\$, p. 510, Acts 1015, p. 831. 
understand how this problem was worked out, it seems best to review the earlier cases bearing on this question.

Down to 1876 the question of a de facto corporation under an unconstitutional statute had not been raised. Of course, there were instances in which the question of the legality of corporate existence was involved, but these were easily taken care of by retrospective validation by statute or by the application of the doctrine of incorporation by legislative recognition or that of the estoppel of the state to question the validity of organizations based upon acquiescence or indirect validation. A brief review of the leading cases arising during this period may be instructive on this point. As early as 1840 , in Commissioners v. Boyd, 20 the Supreme Court of North Carolina had held that the inhabitants of Bath had been incorporated in 1729 by a legislative grant to them of certain lands for the purpose of a common. In Jameson v. People, ${ }^{21}$ an action of quo warranto in the name of the people of the state, the courts of Illinois held that the state was estopped to question the validity of the incorporation of the town of Oquawka in 1851 on the ground that the legislature by statutes enacted in 1852 and 1855 had authorized the town to subscribe to the capital stock of certain corporations therein named and thereby recognized its corporate existence. In 1857 the Supreme Judicial Court of New Hampshire, in Bow v. Allenstown, ${ }^{22}$ decided that the incorporation of a town could be established by, proof of claim and user of corporate powers by the town with the knowledge and assent of the legislature for a period sufficient to furnish evidence of a prescriptive right.

The exercise of the courts of equitable jurisdiction was occasionally invoked, and its limitations were soon realized. Thus, in 1841, the Supreme Court of Tennessee, in Biadley v. Commissioners, ${ }^{23}$ upheld an injunction against the organization of the county of Powell under authority of an act of the legislature of 1839. The bill was filed in January 1840, before the organization was perfected, at least before there was any user of the franchises, and alleged that the act of the legislature was unconstitutional, violating the limitation established by the Constitution as to area, location and population. In 1848, in the case of Ford v. Farmer, ${ }^{24}$ a bill in chancery to enjoin and vacate the county of Hancock, which had been organized under a legislative act of 1844, the court refused to grant the injunction upon the grounds that the power to organize had been executed and, even though the statute was unconstitutional, the county under

\footnotetext{
${ }^{20}$ Supra note 13.

2116 IIl. 257 (1855).

2234 N. H. 351 (1857).

232 Humph. 428 (Tenn. 1841).

2s 9 Humph. 152 (Tenn. 1848).
} 
it had become a political corporation of the state; and that the court of chancery was without power to inquire into the validity of the act.

In 1859 the New York Court of Appeals decided the important case of Rumsey $v$. People. ${ }^{25}$ The case involved criminal jurisdiction and the constitutionality of a statute of 1854 erecting the county of Schuyler, which was attacked upon the ground that the new county did not contain the population required by the Constitution. The court by a vote of five to three upheld the constitutionality of the statute upon the ground that the determination of the fact by the state legislature was beyond judicial control. Johnson, C. J., and Denio, J., in concurring with the majority opinion of Strong, J., delivered oral opinions suggesting that the basis of the decision should be that both branches of the legislature and the executive department of the government had recognized the existence of the county by subsequent acts and thereby put a practical construction on the whole subject. which precluded an inquiry by the judiciary. In Lanning $v$. Carpenter, ${ }^{26}$ decided by the same court in 1859 , in which the existence of the county of Schuyler was again brought in question in connection with a motion to set aside an execution delivered to the sheriff of the so-called county, the court held that its organization was unconstitutional prior to the year 1857, the date of the legislative acts upon which Johnson and Denio, J. J., had upheld its validity.

In 1867 the Supreme Court of Michigan decided the case of People v. Maynard, ${ }^{27}$ a quo warranto proceeding against the acting sheriff of Marquette County. This case involved the organization of the town of Teal Lake, which was attacked upon the ground that a statute of 1857 authorizing its creation did not conform to the constitutional provision as to the enacting clause. The court, speaking through Campbell, J., said:

"If this question had been raised immediately, we are not prepared to say that it would have been altogether free from difficulty. But, inasmuch as the arrangement there indicated had been acted upon for ten years before the recent legislation, and had been recognized as valid by all parties interested, it cannot now be disturbed. Even in private associations, the acts of parties interested may often estop them from relying on legal objections, which might have availed them if not waived. But in public affairs, where the people have organized themselves under color of law into the ordinary municipal bodies, and have gone on year after year raising taxes, making improvements, and exercising their usual franchises, their rights are properly regarded as depending quite as much on the acquiescence as on

2519 N. Y. 41 (1859).

${ }^{26} 20$ N. Y. 447 (1859).

${ }^{27} 15$ Mich. 463 (1867). 
the regularity of their origin, and no ex post facto inquiry can be permitted to undo their corporate existence. Whatever may be the rights of individuals before such general acquiescence, the corporate standing of the community can be no longer open to question. See Rumsey v. People, 19 N. Y. 41, and Lanning v. Carpenter, 20 N. Y. 447; where the effect of the invalidity of an original county organization is very well considered in its public and private bearings. There have been direct legislative recognitions of the new division on several occasions. Laws, $1858, p .23$; Laws, 1861, p. 556; Laws, 1863, p. 22 . The exercise of jurisdiction being notorious and open in all such cases, the state as well as county and town taxes being all levied under it, there is no principle which could justify any court at this late day in going back to inquire into the regularity of the law of 1857."

In State v. County of Pawnee ${ }^{28}$ quo warranto was brought by the attorney general against the board of county commissioners, claiming that the county, which was established in 1868 , had no valid organization on account of fraud and irregularities in its organization. The court upheld the validity of the organization and the authority of the commissioners to exercise the duties of their office upon the ground that by later acts the legislature had recognized the existence of the county and such recognition had cured any fraudulent or defective organization, thus applying the broad doctrine of indirect validation by legislative recognition. At the same term of court, in the case of State v. Coninty of Ford,29 it was held that the state was not estopped to contest the validity of the organization of the county in 1873, notwithstanding legislative recognition by an act prior to the organization of the county de facto.

During this period the direct issue of questions involving de facto or de jure status was mainly avoided by the free application of the doctrine that no one but the state in any instance could question the regularity of the incorporation, a doctrine that proved very convenient in summarily disposing of numerous cases. Thus, in Kayser $v$. Trustees of Bremen, ${ }^{30}$ the Supreme Court of Missouri, although holding that the statute authorizing an optional organization of towns was constitutional, placed its position in refusing to uphold an injunction to restrain the local officers from collecting certain taxes upon the broad doctrine that the authority of the town to act was not subject to collateral attack. Similar decisions in the same and other jurisdictions applied this principle. ${ }^{31}$ The doctrine of collateral attack

2812 Kan. 426 (1874).

2912 Kan. 441 (1874).

3016 Mo. 88 (1852).

31 State v. Rich, 20 Mo. 393 (1855) (criminal case); Miendota v. Thompson, 20 IIl. 197 (1858) (same); Town of Decorah v. Gillis, 10 Iowa 234 (1859) (same); Lusher v. Scites, 4 W. Va. 11 (1870) (tax case); MrcNairy 
was indiscriminately invoked and often confused with that of equitable estoppel, under which the corporation itself or any one who had dealt with it as a corporation is precluded from questioning the de jure character of its existence..$^{32}$ Only in occasional instances was the application of the doctrine of collateral attack or that of equitable estoppel made to depend on a consideration of the de facto character of the corporation. It was held, however, in a few of the early cases, that the plea of nul tiel corporation raised only the issue of its de facto status, and the principle was broadly laid down that the requisites of a de facto corporation were a valid law, an organization in attempted compliance therewith and an user of the corporate franchises. ${ }^{3 a}$ That a valid law was essential to the de facto status, so as to preclude collateral attack, was tacitly admitted in many cases and expressly held in others. ${ }^{34}$

The question whether a de facto corporation could exist under an unconstitutional statute was met in some of the early cases by the assumption that the determination of the factual requirements prescribed by the state constitution for the incorporation of municipalities was solely within the province of the legislature and not subject to judicial review. ${ }^{35}$ It was not until 1876 that the question of an unconstitutional statute as color of authority sufficient to meet the requirement of a valid law was frankly confronted. In that year, in St. Louis v. Shields, ${ }^{80}$ a case in which the defendant pleaded that the statute under which the plaintiff was organized was void as conflicting with the constitutional provision against special legislation, the Supreme Court of Missouri laid down the principle that, for all collateral

v. Nashville, 2 Baxter 251 (Tenn. 1872) (same); Bird v. Perkins, 33 Mich. 28 (1875) (same); Stuart v. School District, 30 Mich. 69 (1874) (samo); Rice v. McClelland, 58 Mo. 116 (1874) (allocation of school funds); Trumbo v. People, 75 Ill. 562 (1874) (contract case); St. Louis v. Shields, 62 Mo. 247 (1876) (same); Alderman v. School Directors, 91 Ill. 179 (1878) (tres* pass case).

32 Dutchess Cotton Mfg. Co. v. Davis, 14 Johns. 238 (N. X. 1817); Den v. Van Houten, 10 N. J. L. 270 (1829); Eaton v. Aspinwall, 19 N. Y. 119 (1859); Mason v. Nichols, 22 Wis. 376 (1867).

${ }^{33}$ Methodist Church v. Pickett, 19 N. Y. 482 (1859); Merriman v. Magiveny, 12 Heisk. 494 (Tenn. 1873).

34 Elizabeth City Academy v. Lindsey, 28 N. C. 476 (1846); Heaston v. Cincinnati F. \& W. R. R., 16 Ind. 275 (1861); Snyder v. Studebaker, 10 Ind. 462 (1862); De Witt v. Hastings, 40 N. Y. Super. Ct. 463 (1876); Krutz y. Paola Town Co., 20 Kan. 397 (1878).

${ }^{35}$ State v. Rich, supra note 31; Lusher v. Scites, supra note 31; Stato v. Dorsey, 28 Ark. 378 (1873).

These decisions were based upon Luther v. Borden, 7 How. 1 (U. S. 1849), in which the Supreme Court refused to go back of the determination of the legislature of Rhode Island as to the legitimacy of the statc government.

${ }^{36}$ Supra note 31. 
purposes, a statute though unconstitutional was color of authority sufficient for a de facto organization.

Five years prior to the decision in St. Louis v. Shields the Supreme Court of Connecticut, in State v. Carroll, si a case involving the validity of acts of a person acting as a justice of the peace who had discharged the duties of the office without authority of the appointing power, undertook to review the historical and legal basis of the de facto doctrine applied to officers. In a monographic opinion, Chief Justice Butler reviewed the English cases and set forth the foundation and limits of this doctrine. As the application of the de facto doctrine to the acts of public. agencies acting as municipal corporations has its historical basis in the early recognition of the official validity of acts of incumbents of offices whose title thereto was defective but whose tenure had been recognized by the public, it may be well to refer briefly to the English doctrine as developed to meet the needs of their situation.

The first reported case in which the act of a de facto officer was upheld is that of The Abbe de Fountaine ${ }^{33}$ in 1431. Thirty years later, upon the accession of Edward the Fourth, Parliament passed a statute confirming all the official acts of the kings of the House of Lancaster who were therein recognized as "late kings of England in deed and not of right." 30 In the less than a score of reported cases down to the beginning of the nineteenth century, we find the limitations of the doctrine broadly set forth in the definition of Lord Ellenborough in Rex v. Bedford Level Corporation, ${ }^{40}$ in which he said that an officer de facto is one "who has the reputation of being the officer he assumes to be, and yet is not a good officer in point of law." In these early cases are to be noted two primary limitations of the doctrine which should always be borne in mind. The first is that there can be no de facto officer if there is a de jure officer in possession of the office, nor can one gain the de facto status by ousting a de jure officer-such a claimant is a mere usurper whose title and acts are void.41 Secondly, in order to constitute one an

3738 Conn. 449 (1871).

38 Y. B. 9 Hen. VI, f. 32. A full statement of this case may be found in Justice Butler's opinion in State v. Carroll, supra note 37, at 458, and in Constantineau, Public Officers and the De Facto Doctrine (1910) 9-10. Both of these authorities also give a list of the early cases.

391 BL. Conims. $\approx 204$.

${ }^{40} 6$ East 356, 368 (1805). Ellenborough's definition closely follows that given by Lord Holt in Parker v. Kett, 12 Mod. 466 (1701): "A steward de facto is none other than he who has the reputation of being the officer he assumes to be, although he is not such in point of law." This broad definition has been universally followed in England and generally approved by the American courts. Petersilea v. Stone, 119 Mrass. 465 (1876).

41 The Abbé de Fountaine, supra note 38 ; MicCraw v. Williams, 33 Gratt. 510 (Va. 1880). 
officer de facto, his entry must be under color of authority and in good faith.".2

Chief Justice Butler, in his opinion in State v. Carroll upon a view of the English authorities, establishes the further point that the notion that "that color can only be conferred by a body" or person having power, or prima facie power, to elect or appoint in the particular case" had up to that time no foundation in the decisions of the English courts. He also found that the majority of the American decisions down to 1870 were in accord with the English precedents, ${ }^{43}$ and that the early New York doctrine to the contrary was based upon a misconception of the grounds of Chancellor Kent's decision in People v. Collins, ${ }^{44}$ as elaborated by the reporter's note to McInstry $v$. Tunner, ${ }^{45}$ and had crept into the definition of a de facto officer through the misrepresentation of the decision in Rex $v$. Lisle as reported by Strange.46 The introduction of the same error into the definition of a de facto officer by Chief Justice Hosmer in McCall v. Byram $M f g . C o .{ }^{47}$ was criticised and the distinction made in Brovn $v$. $O^{\prime}$ Connell ${ }^{48}$ between unconstitutional statutes apparently valid and those manifestly repugnant to the constitution as bearing upon color of authority was repudiated.

As a result of this review of the authorities, Justice Butler formulated the following definition of a de facto officer as embodying a restatement of the earlier decisions: ${ }^{48 a}$

"An officer de facto is one whose acts, though not those of a lawful officer, the law, upon principles of policy and justice, will hold valid so far as they involve the interests of the public and third persons, where the duties of the officer are exercised,

First, without a known appointment or election, but under such circumstances of reputation or acquiescence as were calculated to induce people, without inquiry, to submit to or involke his action, supposing him to be either the officer he assumed to be.

Second, under color of a known and valid appointment or election, but where the officer had failed to conform to some precedent requirement or condition, as to take an oath, give a bond, or the like.

42 Rex v. Lisle, Andr. 163 (1738).

43 Fowler v. Bebee, 9 Mass. 231 (1812); Parker v. Baker, 8 Paige 428 (N. Y. 1840); Taylor v. Skrine, 3 Brevard 516 (S. C. 1815); Carlton v. People, 10 Mich. 250 (1862); People v. Kane, 23 Wend. 414 (N. Y. 1840); People v. White, 24 Wend. 520 (N. Y. 1840); Clark v. Commonwealth, 29 Pa. 129 (1858); Commonwealth v. McCombs, 56 Pa. 436 (1867); Cocko v. Halsey, 16 Pet. 71 (U. S. 1842).

447 Johns. 549 (N. Y. 1811).

459 Johns. 135 (N. Y. 1812).

462 Strange 1090 (1738).

476 Conn. 428 (1827).

4836 Conn. 432 (1870).

${ }^{48^{a}}$ Supra note 37 , at 471 . 
Third, under color of a known election or: appointment, void because the officer was not eligible, or because there was a want of power in the electing or appointing body, or by reason of some defect or irregularity in its exercise, such ineligibility, want of power, or defect being unknown to the public.

Fourth, under color of an election or appointment by or pursuant to a public unconstitutional law, before the same is adjudged to be such."

While the question whether there could exist a de facto office was not directly involved in State v. Carroll, the affirmative of this proposition was distinctly asserted under the fourth subdivision of Justice Butler's definition. This proposition was unchallenged until the decision of the Supreme Court in the well known case of Norton $v$. Shelby County, in which, through Justice Field, the court said without qualification:

"An unconstitutional act is not a law; it confers no rights; it imposes no duties; it affords no protection; it creates no office; it is, in legal contemplation, as inoperative as though it had never been passed."

It thus repudiated in its entirety the fourth subdivision of Justice Butler's definition so far as the creation of an office itself was involved.

That this sweeping assertion, although adopted as the ratio decidendi of the case, was not necessary to the decision, may be seen by a brief reference to the facts. The constitution of Tennessee established in each county but one county court composed of the justices chosen from their respective districts. By a statute enacted in 1867, the governor was given authority to appoint commissioners for Shelby County, who were to exercise the powers given to the board created by the constitution. The validity of the act of these commissioners in issuing bonds was raised by the litigation. The court failed to answer the argument of $\mathrm{Mr}$. Choate that the commissioners appointed by the governor were only exercising powers clearly conferred upon the county, which itself had a constitutional existence. The case was correctly decided, however, for there can be no officers de facto where there are officers de jure who immediately contested their ouster by legal means, as in this case. But from the point of view of Justice Fields, the decision might fairly have rested upon the point that the office itself was without color of validity, since its attempted creation was so palpably contrary to the express provisions of the constitution. We may conclude, therefore, that the de facto doctrine as applied to the creation of offices requires a modification of the language of the fourth divi-

49118 U. S. 425, 442, 6 Sup. Ct. 1121, 1125 (1886). 
sion of Chief Justice Butler's definition so as to read "a public unconstitutional law not plainly invalid."

Since the decision in Norton $v$. Shelby County, in practically every case that has arisen involving the de facto status of a public office or of a public corporation in this country, the court has discussed Justice Field's opinion and compared it with that of Chief Justice Butler in State v. Carroll, and not infrequently has been led to incorporate the one or the other into its opinion as a ready-made authority for a decision it had already reached. It follows that a classification of the later decisions on de facto municipal corporations can best be made with reference to the attitude of the courts on the effect of an unconstitutional statute as color of authority. An attempt will be made to explain the real basis of their divergence and to formulate the principles upon which they were decided.

The statement that there can be no de facto officer unless there exists a de jure office has been advanced in numerous cases, both before and subsequent to the decision in Norton $v$. Shelby County. In 1907, Mr. K. R. Wallach reviewed these cases ${ }^{50}$ and demonstrated that none of them substantiated the doctrine sponsored by Justice Field. He pointed out that in the majority of the cases cited to support the doctrine, a de jure office was in existence, and that in the others the one discharging the duties of the office had entered without the color of authority. The only case that was necessarily decided on the contrary principle was that of Flaucher $v$. Camden, ${ }^{51}$ which has since been overruled by the New Jersey courts. ${ }^{52}$ From an analysis of the cases, Mr. Wallach deduced the following principles as governing the doctrine of de facto officers: ${ }^{52} \frac{1 / 2}{}$

"(1) If there is a de jure office in existence, anyone (a) who enters on such office with color of title as to his appointment or election, or (b) who enters, acts as officer and is recognized as such by the public, is a de facto officer. In this class of cases the legal existence of the office confers color of title upon anyone who has the recognition and acquiescence of the public.

"(2) If there be no office in existence de jure, and the claimant enters with no color of title, under an act of the legislature which is on its face clearly unconstitutional, he is not a de facto officer but a mere usurper.

"(3) If there be no de jure office, and the incumbent enters under an unconstitutional act of the legislature, but one which is not clearly and on its face unconstitutional, and if such incumbent does not otherwise lack color of title, he is a de facto officer. Acquiescence on the part of the public may, perhaps, be an additional requisite.

${ }^{50}$ Wallack, De Facto Office (1907) 22 Pox. Scr. Q. 460.

5156 N. J. L. 244, 28 Atl. 82 (1893).

52 Lang v. Bayonne, 74 N. J. L. 455, 68 Atl. 90 (1907).

$52 \frac{12}{2}$ Op. cit. supra note 50 , at 479 . 
“(4) The officers of de facto municipal corporations are in a distinct class, and so long as the state itself does not attack their title, they are treated as de jure officers."

The first, second and fourth subdivisions of Mrr. Wallach's statement are fully sustained by the decisions relating to de facto offices and may be applied to de facto municipal corporations as well. As to the third subdivision, it is doubtful that it can be unqualifiedly supported either upon legal theory or by the adjudicated cases. Certainly, no such broad principle can reconcile the conflicting decisions relating to de facto municipal corporations. Admitting that an unconstitutional statute apparently valid on its face may give color of authority and evince good faith on the part of those who assume to exercise the corporate franchises, it is difficult to see how, standing alone, it can impart that creative legislative force essential to the existence of a corporate entity. It is submitted that it is only when there also exists a warrant in a valid statute or in the state constitution for the office or corporation whose title to a de facto existence is in question that its right to such a status, either in theory or upon authority, can be accepted.

The existence of a de facto office based upon a de jure existence in potentia by recognition in the state constitution or in general statutes has frequently been applied to sustain public acts by those purporting to act as officer's under an unconstitutional statute or before the statute creating the office has gone into effect. If under the constitution or by a general statute the office is established or recognized, and authority is delegated to an inferior legislative body to establish it by appropriate action, the failure of such inferior body to act will not prove fatal to the de facto character of those who in good faith enter upon the discharge of the duties of the office, which is said to exist in potentia. ${ }^{53}$ For example, in Smith v. Lynch a statute of Ohio authorized the city council to establish a board of health and appoint the incumbents. Without appropriate action by the board, appointments were made and the persons so selected assumed to discharge the functions of the office. To the objection that there was no office to be filled, the Supreme Court of Ohio answered:

"We do not so understand the law. The statute (66 Ohio L. 200) creates the office. It authorizes the council to 'establish' the board, and to fill it by appointment. True, until the council act in the premises, it is a mere potentiality in their hands; yet

53 Brown v. O'Connell, supra note 48; Smith v. Lynch, 29 Ohio St. 261 (1876); Clark v. Easton, 146 IIass. 43, 14 N. E. 795 (1888); Demarest v. Mayor, 147 N. Y. 203, 41 N. E. 405 (1895); Buck v. Eureka, 109 Cal. 504, 42 Pac. 243 (1895). In Buck v. Eureka, supra, the courth revievs most of the earlier decisions applying this doctrine. 
it is none the less an office, known to the law and provided for by law. . . . It is enough that the office is one provided for by law and that the parties have color of appointment, assume to be and act as such officers, and that they are accepted and acknowledged by the public as such to the exclusion of others. Such was the case here. There was both the color and the fact of office."

Peculiarly enough, the doctrine of potential existence was never expressly relied upon in the earlier cases involving de facto corporate status, although there is ground for the assertion that the reason for the decision in People v. Maynard was drawn from the implications of the constitution in regard to the formation of counties. In Ashley v. Board of Supervisors of Presque Isle County ${ }^{54}$ decided by the Circuit Court of Appeals, Sixth Circuit, in 1893, the court, although basing its decision on other grounds, went into the discussion of the de facto status of the county, which had been organized under an unconstitutional statute. While expressing its approval of Justice Butler's conclusions in State v. Carroll, the opinion of the court frankly bases the color of authority for the de facto status of the county upon the doctrine of potential existence. Upon this point the court says: ${ }^{54} 1 / 2$

"But counsel for the defendant lays principal stress upon the doctrine that there cannot be a county de facto where there can be none de jure; and it is argued because the law of 1871 was void when enacted, and gave no authority for organization, there was no law under which Presque Isle County could become de jure a county, and therefore it could not become de facto such. The general proposition is no doubt correct, as a statement of a doctrine of law. But we do not think that proposition, as applied to the case before us, is sound. . The supreme law of the state recognizes counties as political bodies corporate. Their existence is not only permitted, but is essential to the government which is organized. Their corporate character is not given by the legislature. That body, if it deems the organization consistent with public policy, prescribes a method of organization in form. This law, whether operative or not, signified the approval of the legislature of the formation of the new county, and in so far was in execution of its authority under the constitution; and we apprehend the rule to be that an unconstitutional and void law may yet be color of authority to support, as against anybody but the state, a public or private corporation de facto, where such corporation is of a kind which is recognized by, and its existence is consistent with, the paramount law, and the general system of law in the state."

The cases which have refused to accept the principle that an unconstitutional statute can be a sufficient color of authority for

5460 Fed. 55 (C. C. A. 6th, 1893). The court consisted of Taft and Lurton, circuit judges, and Severens, district judge.

$543 / 2$ Ibid. 64. 
a de facto municipal corporation base their conclusion upon the strict logical deduction set forth in Justice Field's famous dictum, and fail to recognize that the de facto doctrine is not founded upon strict legalistic principles, but upon the brond foundations of public policy. It must be admitted that no corporate entity can spontaneously create itself, that it requires the exercise of legislative power to give it the breath of life. But the legislative fiat may be either express or implied, may be found in the fundamental law as well as in the act of the legislature or of the local electorate under the home-rule provisions of the state constitutions. If the state constitution malies provision for cities or counties and delegates the powrer to create them to the legislature under certain restrictions, the failure of the latter to comply with the constitutional requirements will not destroy the color of authority given by the fundamental law. Of course, if there is no such provision in the fundamental law, from which the court can infer a creation of the corporation in potentia, if the corporation sought to be created by an invalid statute is unknown to the constitution or by implication is excluded because the constitution itself establishes the agency which is to perform the functions, there can be no basis for the color of authority requisite to the recognition of a de facto corporation. ${ }^{56}$

Whether one accepts the broad assumption that an unconstitutional statute, which is the only source of the creative act under which the corporation derives its powers, is sufficient or the more logical principle that there must be somewhere a precedent "valid law," if only in the potential existence recognized by the state constitution, is often made to depend upon the view one takes of the effect of the action of our courts in declaring statutes unconstitutional..$^{57}$ That this question is not necessarily involved in the determination of a de facto corporate existence should be obvious when we remember that "color of title" does not mean and never has meant legal authority, but only the appearance of authority. An unconstitutional statute, therefore, may be sufficient color of authority, provided there is somewhere at the same time a war-

55 See Warren, Collateral Attack on Incorporation (1907) 20 HArv. L. REv. 456, (1908) 21 ibid. 305.

56 Hildreth v. MicIntire, 1 J. J. Marsh. 206 (Ky. 1829) ; People v. Town of Nevada, 6 Cal. 143 (1856); Colton v. Rossi, 9 Cal. 595 (1858); Snyder v. Studebaker, supra note 34; Att'y Gen. v. MIarr, 55 Mlich. 445, 21 N. W. 883 (1885); Norton v. Shelby County, supra note 49; Eaton v. Walker, 76 Mich. 579, 43 N. W. 638 (1889); City of Guthrie v. Territory, sumpra note 12; Atchison, T. \& S. F. R. R. v. Kearney County, 5s Kan. 19, 48 Pac. 583 (1897).

57 For a discussion of this question, see Field, Effect of an Unconstitutional Statute (1926) 1 IND. L. J. 1; Comment (1926) 39 HARv. L. REv. 373. 
rant in law for the creation of the corporate entity which lays claim to a de facto existence.

Of the leading cases cited to support the view that there can be no de facto corporation organized under an unconstitutional statute, it is doubtful if any one of them cannot be supported upon other grounds. In Brandenstein v. Holve, ${ }^{68}$ in which a writ of mandate was prayed for to compel the levying of a tax to meet the principle and interest on bonds issued by' a levee district, the court sustained the plea that the district had no do facto status because organized under an unconstitutional statute, but the statute had been declared void by the supreme court ${ }^{\circ 0}$ prior to the attempted organization, so that plainly it constituted no sufficient color of authority.

In Atchison, T. \& S. F. R. R. v. Keurney County, ${ }^{\text {(D) }}$ which is often cited as upholding the view that there can be no de facto municipal corporation under an unconstitutional statute, the action was upon certain warrants issued by the defendant before it had become organized de jure. The court held that the earliev statute under which the organization was attempted was void, as the legislature failed to comply with the mandatory provisions of the constitution, and that the defect was patent upon the face of the act itself. That such was the basis of the decision may be seen by reference to another case, Riley $v$. Garfield Township ${ }^{61}$ decided at the same term, which held that the defendant, being organized under an unconstitutional statute before it was adjudged invalid, was a de facto corporation under the rulo enumerated in State v. Carroll. It is also noteworthy that the Circuit Court of Appeals refused to follow the decision of the Supreme Court of Kansas in Atchison, T.\& S. F.R. R. v. Kearney County, holding that the constitutional irregularity in the enacting clause of the statute was not sufficiently patent to deprive the act of color of authority, and that a de facto organization of the county was effected thereunder. ${ }^{02}$

In the two cases entitled Town of Winneconne $v$. Village of Winneconne, ${ }^{63}$ decided at the same term by the Supreme Court of Wisconsin, the plaintiff sued to recover from the defendant certain liquor license moneys collected by it during a period when it was claimed the village had no legal existence because organized under an unconstitutional statute. In the first case, brought for moneys collected in 1893, the plea was sustained, the court

58101 Cal. 131, 35 Pac. 562 (1894).

58 Moulton v. Parks, 64 Cal. 166, 30 Pac. 613 (1883).

co Supra note 56.

6158 Kan. 299, 49 Pac. 85 (1897).

62 Speer v. Board of Commissioners, 88 Fed. 749 (C. C. A. 8th, 1808). Accord: White v. City of Quanah, 27 S. W. 839 (Tex. Civ. App. 1894).

63 111 Wis. 10, 86 N. W. 589 (1901). 
holding that the curative act of $1897^{\circ 4}$ could not validate a corporation void ab initio, and that service upon the village officers prior to the general validating act was of no effect to give jurisdiction over the defendant. In the second case brought for moneys collected in the two subsequent years, in which service was made after the general validating act, the court allowed recovery upon the ground that, by the terms of the validating act, the condition imposed upon the village the liabilities of its predecessor, denominated as the "pre-existing voluntary organization." In McDonald $v$. Doust, ${ }^{65}$ in which also the doctrine of Norton v. Shelby County is reiterated, the county organization which the statute attempted to set up was in direct violation of the express provision of the constitution, ${ }^{65}$ which had established the counties of the state by recognizing the several counties of the territory as they existed at the time of its adoption and had failed to delegate any power to the legislature to establish new counties.

In the above cases, it appears that the true basis for denying to the corporation a de facto status lay in the absence of any legislative act to give vitality to its creation. An examination of the cases holding, some of them unreservedly, that a de facto office or municipal corporation can exist under color of an unconstitutional statute will reveal that in no instance did the invalid act give life to the corporation, but that either in other valid acts or in the constitution itself the office or the corporation was potentially created. Thus, in St. Louis 2'. Shiclds, ${ }^{\text {or }}$ where the question was one of collateral attack, there was not only recognition in the constitution itself but also by other acts of the state. In School District No. $25 v$. State ${ }^{\text {os }}$ the plea was made in defense to suit on bonds issued by the district that the acts creating it were without authority in law and under an unconstitutional statute changing the county boundaries; but the court in asserting the de facto character of the defendant relied upon the general laws of the state relating to the organization of school districts, which gave it the requisite legislation sanction. In Burt v. Winona \& St. Paut $R . R .{ }^{c}$ the constitution vested the judicial power in a supreme court and such other inferior courts as the legislature from time to time might create by a two-thirds vote. It was held that a municipal court organized under a statute invalid for failure to comply with the twothirds provision was a de facto court. In Coast Co. v. Spring

\footnotetext{
es Wis. Laws 1897 , c. 5.

6511 Idaho 14, 81 Pac. 60 (1905).

66 IDAHO CoNST. Art. XVIII, § 1 (1889).

${ }^{67}$ Supra note 31.

6829 Kan. 57 (1882).

69 31 Minn. 472, 18 N. W. 285 (1884).
} 
Lake ${ }^{70}$ it was held in a collateral proceeding that the fact that the statute under which the defendant borough was organized had subsequently been declared unconstitutional in another case did not destroy its de facto status, which would continue until a judgment of ouster in quo warranto proceedings instituted by the state was executed. Here again boroughs under the name of towns were potentially created by the New Jersey constitution. ${ }^{71}$ In both Thompson v. Couch ${ }^{72}$ and Lang v. Bayonne, ${ }^{79}$ the offices in question existed by virtue of valid statutes other than the unconstitutional acts under which the attempt was mado to organize. So, also, in Wendt v. Berry ${ }^{74}$ and Ball v. Eady Co. ${ }^{70}$ the Supreme Court of Kentucky, in holding that certain cities were de facto of the class under which they purported to operate by virtue of unconstitutional statutes, pointed out that cities were potentially created and their classification fixed by section 156 of the Constitution of $1890 .{ }^{78}$

The principle that color of title under an unconstitutional statute can exist only where there is some other valid law under which the organization may be effected, or at least an authority in potentia by the state constitution, has its counterpart in the negative propositions that there can be no color of authority in an unconstitutional statute that plainly so appears on its face or that attempts to authorize the ousting of a de jure or de facto municipal corporation upon the same territory; in the one case the fact would imply the imputation of bad faith, in the other the new organization must be regarded as a mere usurper. It is upon this principle that the decision in Norton $v$. Shelby County and similar cases should be predicated. An illustration of the application of the distinction above set forth may be found in comparing Hildreth $v$. McIntire ${ }^{77}$ with Nagel v. Bosworth, ${ }^{78}$ both of which involved the de facto character of courts erected under unconstitutional statutes. In the former case, the legislature of Kentucky sought to abolish the Court of Appeals established by the constitution and to create another court of appeals in lieu of it. It was held that new organizations could not exist

7056 N. J. Eq. 615, 36 Atl. 21 (1896). To the same effect see: Att'y Gen. v. Town of Dover, 62 N. J. L. 138, 41 Atl. 98 (1898).

71 N. J. Const. Art. I, § 19, Art. IV, § 7 (11) (1897) ; Hermann v. Guttenberg, 63 N. J. L. 616, 44 Atl. 758 (1899).

72144 Mich. 671, 108 N. W. 363 (1906).

73 Supra note 52.

74154 Ky. 586, 157 S. W. 1115 (1913).

$75193 \mathrm{Ky} .813,237$ S. W. 670 (1922).

${ }^{76}$ See, also, in accord: State v. Gardner, 54 Ohio St. 24,42 N. E. 009 (1896) (opinion by Spear, J.) and cases cited therein; Speer v. Board of Commissioners, supra note 62.

77 Supra note 56.

$78148 \mathrm{Ky} .807,147$ S. W. 940 (1912). ' 
de facto, as a court of appeals de jure was in existence and the act of the legislature was ultra vires and palpably in violation of the constitution. In the second case, however, which held that a circuit court organized under an unconstitutional statute had a de facto existence, it was pointed out that circuit courts were not directly created but were recognized by the constitution, ${ }^{79}$ which expressly provided that a circuit court shall be established in each county of the state.

As a result of this analysis of the cases the following principles may be deduced which seem to reconcile the apparently conflicting decisions:

I. The color of authority requisite to the organization of a de facto municipal corporation may be:

1. A valid law enacted by the legislature.

2. An unconstitutional law, valid on its face, which has either (a) been upheld for a time by the courts or (b) not yet been declared void; provided that a warrant for its creation can be found in some other valid law or in the recognition of its potential existence by the general laws or constitution of the state.

II. There can be no de facto municipal corporation unless, either directly or potentially, such a de jure corporation is authorized by some legislative fiat.

III. There can be no color of authority in an unconstitutional statute alone, the invalidity of which is apparent on its face.

IV. There can be no de facto corporation created to take the place of an existing de jure corporation, as such an organization would clearly be an usurper.

It is submitted that the principles thus formulated are comprehensive enough to cover all the cases in which the issue of the de facto status of a municipal corporation has been brought in issue. Even the broad assertion often made that an unconstitutional statute is in all cases sufficient color of authority, as in the opinion of the court in Albuquerque v. Water Supply Company, ${ }^{80}$ will be found upon examination to be subject to the limitations above set forth.

To the objection that the principles here invoked do not meet the conflict in the views expressed by the courts in these different cases, the answer must be frankly made that the opinions themselves are irreconcilable. To the more serious objection that they will not explain satisfactorily the numerous cases in which the state itself is precluded from ousting an irregular municipal corporation by quo warranto, because of what is indiscriminately called its acuuiescence or laches or estoppel, ${ }^{81}$ the

${ }^{79} \mathrm{Kr}$. CoNST. $\$ 125$ (1891).

so 24 N. M. 368, 174 Pac. 217 (1918). See recognition of cities in N. MT. Corsst. Art. IV, $\$ 24$, Art. IX, $§$ 12, 13 (1911).

hameson v. People, supra note 21; People v. Miaynard, supra note 27; 
reply must be that the so-called estoppel of the state to question the right of a municipality to corporate existence is based upon an entirely different principle which does not necessarily involve any consideration of the de facto doctrine. This question, as well as that of the relation of the de facto status to the doctrines of collateral attack and of equitable estoppel, requires a separate treatment for any adequate or satisfactory discussion.

State v. Leatherman, supra note 13; State v. Des Moines, 96 Iowa 521, 65 N. W. 818 (1896); McCain v. Des Moines, 174 U. S. 168, 19 Sup. Ct. 644 (1899); State v. McLean County, 11 N. D. 356, 92 N. W. 385 (1902); Soule v. People, 205 Ill. 618, 69 N. E. 22 (1903); People v. Alturas County, 6 Idaho 418, 55 Pac. 1067 (1889) ; Att'y Gen. v. Methuen, 236 Mass. 504, 129 N. E. 662 (1921). 